\title{
СУЧАСНІ ІННОВАЦІЙНО-ТЕХНОЛОГІЧНІ ПРИЙОМИ ТА ШЛЯХИ ПОЛІПШЕННЯ ВИВЧЕННЯ ТЕМИ “ГОСТРИЙ АПЕНДИЦИТ ТА ЙОГО УСКЛАДНЕННЯ” СТУДЕНТАМИ МЕДИЧНОГО ФАКУЛЬТЕТУ
}

\author{
О. М. Дмитрук
}

ДВНЗ “Івано-Франківський національний медичний університет”

\section{THE MODERN INNOVATION-TECHNOLOGICAL METHODS AND THE WAYS OF IMPROVING THE THEME STUDYING “ACUTE APPENDICITIS AND ITS COMPLICATIONS” BY STUDENTS OF THE MEDICAL FACULTY}

O. M. Dmytruk

\author{
Ivano-Frankivsk National Medical University
}

\begin{abstract}
У роботі узагальнено досвід кафедри хірургії № 1 ІФНМУ вивчення студентами теми “Гострий апендицит та його ускладнення”; впровадження й удосконалення інноваційних технологій при використанні інтерактивних методів навчання на всіх етапах навчального процесу з вивчення спеціальності, в т. ч. під час проведення загально-курсової конференції з актуальних проблем клініки, діагностики та лікувальної програми. На етапі визначення кінцевого рівня знань використовуються вирішення кейс-завдань, ігрові та неігрові методи модельованого навчання, а якість отриманих знань оцінюється поточним та підсумковим контролем.
\end{abstract}

The experience of the Ivano-Frankivsk National Medical University Department of Surgery №1 of the innovative technologies implementation and improvement of used interactive teaching methods at all stages of the students' learning process of studying specialty in the medical faculty is presented. At this stage of determining the final level of knowledge, the test case-solving tasks, gaming and non-gaming techniques of simulated training are used and the quality of knowledge is assessed with current and final module control.

Вступ. Інтеграція України в Європу передбачає реформування вищої освіти та входження в Європейський освітній простір. Цей процес вимагає нових підходів до організації навчального процесу у вищих навчальних закладах, що було задекларовано Законом України “Про вищу освіту” в новій редакції від 01.07.2014 року № 1556-VII, що визначає європейську кредитну трансферно-накопичувальну систему організації освітнього процесу, яка полягає у накопичуванні та перезарахуванні кредитів. Вона грунтується на визначенні навчального навантаження здобувача вищої освіти, необхідного для досягнення визначених результатів навчання, що обліковується у кредитах. Відповідно до статті 47 Закону України освітній процес у навчальному закладі провадиться через систему науково-методичних і педагогічних заходів та спрямований на передачу, засвоєння, примноження і використання

(C) О. М. Дмитрук знань, умінь в осіб, які навчаються [1, 2]. Найбільш актуальною в модулі 1 “Абдомінальна хірургія” ми вважаємо тему “Гострий апендицит та його ускладнення”, діагностика і принципи лікування якого актуальні для лікаря будь-якого профілю. Одним із напрямків для створення комфортних умов навчального процесу $є$ використання інноваційних технологій і в першу чергу інтерактивних методів навчання [3, 4, 5]. Цей метод передбачає як підвищення якості викладання теоретичного курсу з використанням сучасних технологій (проблемні лекції, лекції майстер-клас, лекції прес-конференції) [6], так і практичної підготовки, де поряд з традиційними підходами (робота студента 3 хворими, відшліфування ним майстерності визначення патологічних симптомів та ознак) широко застосовують технології ситуаційного навчання (кейс-метод, імітація рольових ігор) $[4,6,7]$. Не менш важливою $є$ правильна організація самостійної позааудиторної 
роботи студента (СПРС) з вивчення і оволодіння окремими темами кредиту із залученням низки інноваційних технологій: використання інтернетмережі, електронних варіантів напрацювань кафедри, кафедр інших вузів та сприяння до участі студентів у науково-дослідницькій роботі.

Для контролю за отриманими знаннями та вміннями використовуємо тестову і рейтингову системи оцінювання якості теоретичних знань, визначаючи як поточний, так і кінцевий рівень на кожному занятті, а також підсумково-модульний контроль (ПМК). При цьому оцінюють роботу студента біля ліжка хворого, виконання ним діагностичних мануальних прийомів, уміння встановити топічний та кінцевий діагноз і визначити алгоритм лікування. Отже, одним із важливих напрямків інтерактивного навчального процесу є використання сучасних технічних засобів, необхідних для найбільш ефективного сприйняття та засвоєння матеріалу [7].

Мета роботи - систематизувати й узагальнити досвід інтерактивного, інноваційного підходу у навчанні студентів медичного факультету за темою “Гострий апендицит та його ускладнення” і продемонструвати його роль у вдосконаленні засвоєння ними знань та вмінь з етіопатогенезу, клініки, діагностики і лікування захворювання.

Основна частина. Головна мета інноваційної освіти - забезпечення та розвиток творчого потенціалу людини, а також її всебічний розвиток. Цим умовам відповідає використання інтерактивних методів навчання.

Методи активного навчання можуть використовуватися на різних етапах навчального процесу:

I етап - первинне оволодіння знаннями. Це можуть бути проблемна лекція, евристична бесіда, навчальна дискусія та ін.

II етап - контроль знань (закріплення). Можуть бути використані такі методи, як колективна розумова діяльність, тестування.

III етап - формування професійних умінь, навичок на основі знань і розвиток клінічного мислення, можливе використання модельованого навчання, ігрові й неігрові методи.

Інтерактивні методи відіграють важливе значення на всіх етапах навчання. Проте при вивченні актуальної теми модуля 1 “Абдомінальна хірургія” “Гострий апендицит та його ускладнення” особливого значення вони набувають на етапі формування професійних умінь та навичок у процесі курації хворого. Результатом цього етапу є вироблення клінічного мислення [6]. На кафедрі хірургї̈ № 1
ІФНМУ навчання студентів медичного факультету здійснюється за типовою програмою $з$ дисципліни “Хірургія” (2008) зі змінами, внесеними у Положення про організацію освітнього процесу, в якому передбачено усі види діяльності та зміни, які були введені в ІФНМУ в 2015-2016 навчальному році. Враховуючи роз'яснення і рекомендації по реалізації наказу МОН України від 26 січня 2015 року № 47 “Про особливості формування навчальних планів на 2015/2016 навчальний рік” й окремих норм Закону України “Про вищу освіту”, викладених у листі МОН України від 13.03.2015 року № 1/9-126, Вчена рада ІФНМУ прийняла рішення, яке регламентує питання переходу на 600-годинне навантаження науково-педагогічних працівників. При цьому на основі типових навчальних планів, надісланих Центральним методичним кабінетом 3 вищої медичної (фармацевтичної) освіти, розроблені та затверджені Вченою радою університету для студентів 2015 року вступу робочі навчальні плани. Вони передбачають зміни в розподілі годин для всіх дисциплін. При цьому коригування робочих навчальних програм із дисциплін проводилося з врахуванням адаптації до нових навчальних програм, наявного кадрового потенціалу та не перевищувало 20 \% аудиторного навантаження.

На основі цих документів кафедра внесла зміни в Робочу програму з дисципліни “Хірургія”, згідно 3 якою протягом 7-8 семестрів навчання студенти вивчають і засвоюють два змістові модулі: № 1 (“Ургентна абдомінальна хірургія”) та № 2 (“Хiрургічна гастроентерологія та проктологія”), а саме 5 кредитів ECTS, які складають 150 год, у т. ч. аудиторних 80 (12 лекцій і 68 практичних занять) та 70 год СПРС. Програмою передбачено два ПМК, який проводиться на останніх заняттях другого кредитного терміну. Вивчення цього модуля здійснюється за розкладом університету у спарених парах (4 год) з вивченням двох тем.

Теоретична підготовка студентів здійснюється під час лекцій, практичних занять та самостійної роботи з вивчення окремих тем. При проведенні лекцій нами широко застосовуються методи “інформаційного повідомлення”: аудіовізуальні презентації, відеофільми, графіки, інтегральні схеми патогенезу й диференційної діагностики різних гострих захворювань органів черевної порожнини, відео- та мультимедійні презентації з демонстрацією дослідження хірургічного статусу хворих 3 різною патологією. Поєднання коментарів лектора з відеоінформацією та анімацією значно мотивує 
увагу слухачів до викладання матеріалу за темою. Досить цінним під час лекції є презентація відео чи мультимедійних преференцій, діагностики та лікування окремих пацієнтів з практики лектора. Подальше засвоєння лекційного матеріалу проходить у вигляді співбесіди у діалоговому режимі (питання-відповідь). Таким чином, при викладанні теоретичного матеріалу кафедра переважно використовує дидактичні засоби навчання, варіантом якого є проблемна лекція, що створює певні ситуації і залучає слухачів до їх вирішення. Така методика, за даними анкетування студентів, при складанні ПМК дала їм можливість швидше і якісніше засвоїти тему, а рівень збережених знань становив 60-75 \%, тоді як при традиційному викладенні (на паперових носіях) - 20-25 \%. Цьому також сприяє надання студентам лекційних матеріалів на електронних носіях, що уможливлює в будь-який час протягом 15-20 хв оновити в пам’яті надану інформацію.

Засвоєння теоретичного матеріалу на практичних заняттях проводиться також із залученням інтерактивних методик: імітаційних ділових ігор, різних видів дискусій, семінарів-тренінгів, а за допомогою кейс-методу (активного проблемноситуаційного аналізу) - вирішенням конкретних завдань-ситуацій. Не менш важливим на початку заняття є експрес-метод тестового контролю засвоєння теми в домашніх умовах шляхом вирішення тестів, кейс-завдань кожним студентом. Кафедрою розроблено 109 кейс-ситуаційних завдань з різних тем ургентної та планової абдомінальної хірургії і проктології, а також використовуються ситуаційні завдання комп’ютерного контролю, розв’язування блоку завдань 3 хірургії, тестів КРОК-2. Крім цього, засвоєння теми відбувається шляхом дискусії і відповідей на окремі запитання, висвітлених у методичних вказівках для студентів.

Наступним етапом є засвоєння практичних навичок біля ліжка тематичного хворого. Як правило, група студентів викладачем ділиться на 3-5 підгруп по 2-3 студенти, які самостійно проводять загально-терапевтичне обстеження пацієнта. Дослідження місця захворювання проводиться під контролем викладача.

Вивчення 1-2 теми “Гострий апендицит та його ускладнення” здійснюється на спарених парах 3 засвоєнням на кожному занятті двох тем: “Визначення, анатомо-фізіологічні відомості, етіопатогенез, клінічна та патологоанатомічна класифікація. Клініка, діагностика, диференціальна діагностика.
Тактика лікування” й “Атипові клінічні картини гострого апендициту. Ускладнення гострого апендициту та апендектомії. Діагностична та лікувальна програми”. На другому етапі заняття студенти працюють з хворими, які перенесли ургентну апендектомію. В клініці 90 \% апендектомій виконуються лапароскопічною методикою, оскільки в кожній ургентній бригаді є хірург, підготовлений і атестований по лапароскопічних оперативних втручаннях. Так, за 2015 рік у клініці із 137 апендектомій 110 виконано лапароскопічно при різних формах, у т. ч. у 2-х при перфоративному апендициті та дифузному перитоніті. Із 27 хворих конверсію на типову апендектомію виконано у 9, решті хворих типову апендектомію виконано первинно. Таким чином студенти мають можливість ознайомитись із найсучаснішим методом лікування. Вважаємо доцільним демонструвати хворого з іншими захворюваннями, які симулюють гострий апендицит 3 метою диференційної діагностики. За навчальний курс усі студенти мають можливість оглянути хворих $з$ типовою клінікою гострого апендициту. 3 метою поглиблення вивчення цієї теми щорічно під керівництвом завідувача кафедри, керівника гуртка та викладачів проводиться курсова студентська наукова конференція з виступом студентівгуртківців з ключових питань клініки, діагностики та методів лікування гострого апендициту і його ускладнень з наступною дискусією та доповненням $з$ особистої практики професорсько-викладацького складу.

Досить важливим у структурі кредитно-модульної системи навчання є оцінка якості отриманих знань та вмінь. Кількість балів на кожне заняття $є$ сумою від оцінки виконання трьох завдань: тестовий комп’ютерний контроль, практичних навичок (практичний тренінг, рішення ситуаційних завдань, виконання мануальних прийомів визначення окремих симптомів та вміння інтерпретувати результати лабораторно-інструментальних методів дослідження), усна відповідь. Максимальна кількість балів за поточну діяльність студента складає 120. Студент допускається до ПМК 1-го модуля при умові виконання вимог навчальної програми та в разі, якщо він набрав не менше 56 балів, ПМК є завершальним етапом оцінювання знань. Він проводиться за спеціально розробленим протоколом із фіксованою кількістю балів, максимум - 80 балів, з яких: тести в кількості 40 (мінімум 30 балів); 4 практичних навики, кожний - по 5 балів (20 балів); вирішення ситуаційного завдання з визначенням патології, 
варіанта клінічного перебігу, складання діагностичної програми, методів хірургічного і медикаментозного лікування (20 балів). ПМК вважається зарахованим, якщо студент набрав мінімально 50 балів.

Впровадження і удосконалення інноваційних методів при кредитно-модульній системі навчання 3 хірургії дало певні позитивні зміни в показниках успішності. Так, в 2014-2015 н. р. сумарний бал на ПМК складав 100-119 балів у 13,75 \%; 120-139у 40 \%; 140-159 - у 37,5 \%; 160-179 - у 8,75 \%, то в 2015-2016 н. р. питома вага найнижчої оцінки (100-119) була значно меншою і складала 1,25 \% та значно зріс відсоток студентів з балом 120-139 до 56,25 \%, хоча не відмічено значних змін з боку студентів із високим рівнем знань, тобто балом 140-159 - 36,25 \% і 160-179 - 6,25 \%. Слід відмітити зменшення кількості студентів, котрі були не

\section{Список літератури}

1. Організація навчального процесу у вищих навчальних закладах Міністерства охорони здоров’я України в умовах впровадження Закону України “Про вищу освіту” (за підсумками моніторингу в 2016 р.) / Ю. С. П’ятницький, І. В. Мельник, М. О. Поліщук [та ін.] // Медична освіта. - 2016. - № 2. - С. 29-35.

2. Корда М. М. Шляхи імплементації Закону України “Про вищу освіту”в Тернопільському державному медичному університеті / М. М. Корда, А. Г. Шульгай, I. М. Кліщ // Медична освіта. - 2016. - № 2. - С. 34-38.

3. Ковальчук Л. Я. Новітні шляхи вдосконалення підготовки фахівців у Тернопільському державному медичному університеті імені І. Я. Горбачевського / Л. Я. Ковальчук // Медична освіта. - 2010. - № 2. C. 27-30.

4. Dent J. R. A practical guide for medical teachers / J. R. Dent, R. M. Harden. - Churchill Livengstore Elsevier: Edinburgh, London, New York, Oxford, Philadelphia, St. Louis, Sydney, Toronto, 2009. - 435 p. допущені до складання ПМК внаслідок невиконання навчального плану, з 12 до 6 \%. Таким чином, вивчення модуля 1 “Абдомінальна хірургія” відповідно до провідних засад Болонського процесу заслуговує на подальше вдосконалення, що суттєво сприяє підвищенню якості отриманих теоретичних знань і необхідних практичних навичок студентами та наближає процес навчання до вирішення актуальних проблем і вимог сучасності.

Висновок. Інтерактивні, інноваційні методи підвищують ефективність та результативність навчання при їх використанні на етапах навчального процесу. Особливе значення вони набирають при роботі студентів з хворими і формуванні професійних вмінь та навичок, для чого необхідно систематизувати, уніфікувати техніку і послідовність виконання практичних навичок при вивченні теми “Гострий апендицит та його ускладнення”.

5. Удосконалення засвоєння практичних навичок i методик студентами та лікарями-інтернами - важлива складова кадрової перебудови первинної ланки медичної допомоги населенню України / О. П. Волосовець, Ю. С. П’ятницький, І. С. Вітенко [та ін.] // Медична освіта. - 2012. - № 3. - С. 5-7.

6. Aronson L. Twelve tips for teaching reflection at all level of medical education / L. Aronson // Med. Teacher. 2011. - Vol. 33 (3). - Р. 200-205.

7. Використання інтерактивних методів навчання при вивченні основ внутрішньої медицини / О. С. Хухліна, Л. В. Каньовська, О. С. Воєвідка [та ін.] // Впровадження нових технологій за кредитно-модульної системи організації навчального процесу у ВМ(Ф)НЗ III-IV рівнів акредитації : матеріали Всеукр. навч.-наук. конф., присвяченої 55-річчю Тернопільського державного медичного університету імені I. Я. Горбачевського МO3 України (Тернопіль, 26-27 квітня 2012 р.). - Тернопіль : Укрмедкнига, 2012. - С. 415-416. 